\title{
THE EFFECT OF ORGANIZATIONAL STRUCTURE AND LEADERSHIP STYLE ON TEACHER PERFORMANCE IN PRIVATE SECONDARY SCHOOL
}

\author{
Happy Fitria*,Mukhneri Mukhtar**,Makruf Akbar*** \\ University Teachers Association Indonesia of Palembang \\ State University of Jakarta \\ State University of Jakarta \\ happyfitria2006@gmail.com \\ mukhnerimukhtar@unj.ac.id \\ makrufakbar@unj.ac.id
}

\begin{abstract}
The objective of the research were to analyze the influence of organizational structure, and leadership, to teacher performance in the private secondary school in Palembang city. This research method using quantitative method with path analysis technique (path analysis). Samples in this study were 326 teachers from 1,773 private junior high school teachers in Palembang city. The finding of the study showed that: (1) there was a direct positive effect of organizational structure to teacher performance, (2) there was a direct positive effect of leadership to teacher performance,. It is suggested to private junior high school teachers of Palembang city that in improving the performance of teachers can pay attention to the variable of good organizational structure, and leadership, because it is believed as a factor that can encourage the creation of good teacher performance.
\end{abstract}

Keywords : Organizational Structure, Leadership, And Performance.

One of the factors supporting qualified graduates is teacher performance. The general public will ultimately always argue that great teachers are teachers who can produce successful graduates in education. The performance of the teacher (job performance) is the result achieved by the teacher in carrying out the tasks assigned to him based on skills, experience and sincerity and the use of time. Teachers who have good performance value will certainly have an impact with the results of its activities mainly related to teaching and learning process, where the output will increase both in quality and quantity. Teacher performance should always be improved given the challenges of education to produce quality human resources that can compete in the increasingly tight global era. The performance of the teacher (performance) is the result achieved by the teacher in carrying out the tasks assigned to him based on his skills, experience, and sincerity as well as the efficient and effective use of time.

An organization in this school, the division of tasks optimally will be able to improve performance. This is because the division of tasks from the top management to the bottom is clear and structured. Pranata (2009: 30), The right leadership style of the principal will motivate teachers in improving their work morale. In order for human resources in running an organization wheel can work effectively and efficiently, then leadership that plays a very important role to influence and move subordinates so as to achieve the goals set.

In addition to the leadership style of the principal, other factors that affect the success of an education system are trusts. Trust becomes very important because with trust, a teacher can trust the leader with all his decisions and can trust the organization where it shelter. According to Rivai and Silvana (2009: 284) organizations that have good leadership will be easy in laying the foundation of trust on its members, while organizations that do not have good leadership will be difficult to gain the trust of 
its members. The confidence of private junior high school teachers and their leadership policies can be acknowledged as still low. This is seen from the view of private junior high school teachers who assess private junior secondary school is still below the quality standards of the country. Many private school teachers who think teaching in private schools are not as proud and profitable as teaching in public schools

The performance of private junior high school teachers in Palembang still needs serious attention, according to data on the value of UKG score in 2015, teachers in South Sumatera only get an average of 48.62 , and is the $22 \mathrm{nd}$ of 34 provinces in Indonesia. While the data obtained from the education office of Palembang city in 2016 private junior high school teachers who have been certified only 223 teachers from 1773 existing teachers. Daily Sumatera Express also wrote that 55\% of private junior high school teachers in Palembang City still need to get training and workshops on how to prepare innovative teaching materials that students can easily understand.

Teaching materials provided still use the old teaching method, this is because the teacher does not have to maximize its ability. Much of the background of that, based on the experience of researchers, when teaching in private junior Palembang city, among others, the division of tasks that have not been well structured, teachers sometimes have to teach with a different field of study with competence. The leadership style of the principal is still authoritarian, so the teacher has not been able to issue opinions for the good of the school. This has led to the low trust of teachers and principals and schools.

Through a survey conducted by researchers in private junior secondary schools in Palembang, there is still a gap between expectations with existing reality, such as the performance of teachers not yet maximal, still often leaving the class during class time, some teachers have not fulfilled the required academic qualifications, lack of participation in following the seminar, training, workshop, and so forth. So it does not support to perform the task professionally. The reason for this is the lack of optimal school organizational structure in the division of tasks, the leadership style of the headmaster is still authoritarian, and rarely do the guidance to the teacher, so that the discipline of work is low and the low level of teachers' trust in the leadership and school, so sometimes switch to another school better.

So the fundamental problem in this research is limited to the influence of organizational structure, leadership style, and trust on job performance of the teachers in private junior high school (SMP) in Palembang city with problem formulation as here, is there a direct influence of organizational structure on performance ?, is there a direct influence of leadership style on performance ?, is there a direct influence of trust on performance ?, is there any direct influence of organizational structure to trust ?, whether there is direct influence direct leadership style to trust?

\section{Performance}

A.Hale, (2004: 2): job performance is doing meaningful work in effective and efficient ways ", this definition confirms performance is doing meaningful work in an effective and efficient way. Jex and Britt, (2008: 96) defines performance as, "job performance is all of the behaviors employees engage in while at work". This definition asserts that performance is all the behavior of employees who are engaged in the work. In harmony with that definition, Campbell was quoted as saying by Jex and Britt, "job performance represent behaviour employees engage in while at work that contribute to organizational goals". Campbell stated that performance is the behavior of the employees involved while in the workplace that contribute to achieving organizational goals.

According Mangkunegara, (2009: 67) performance is the work of quality and quantity achieved by an employee in carrying out its duties with the responsibility given to him. The high performance of workers is closely related to the reward system applied by the institutions / organizations where they work. Incorrect granting of honor can affect the improvement of one's performance. Performance for teachers can generally be measured through: (1) Ability to create lesson plans; (2) Ability to implement 
lesson plans; (3) Ability to carry out evaluation; (4) Ability to follow up evaluation result.

Ivancevich and colleagues, (2008: 170) who stated that the performance is: "job performance as the desired results of behavior". According to this concept, performance is the expected result of behavior. Performance is also a function of (1) the capacity to perform matters relating to the degree of processual relationships within a relevant individual between tasks with skills, abilities, knowledge, and experience, (2) opportunities to engage in activities related to the availability of equipment and technology, and (3) willingness to connect with desire and willingness to use effort to achieve performance.

The performance concept proposed by Colquitt et al. (2009: 37) is "job performance asthe value of the set of employee behaviors that contribute, either positively or negatively, to organizational goal accomplishment". This concept explains performance is the value of a set of employee behaviors that contribute, either positively or negatively to the fulfillment of organizational goals. So it can be synthesized that what is meant by the performance in this research is the performance of a person in working for a certain time. The indicators of performance, namely: quality of work, work accuracy, initiative, ability, and communication.

\section{Organizational Structure}

Gibson et al, (2012: 398) says "organizational structure is the pattern of jobs and group of jobs in an organization. An important cause of individual and group behavior ". The organizational structure is the pattern of work and group work within an organization. Organizational design and structure has always been an important factor influencing the behavior of individuals and groups within the organization.

George and Jones, (2012: 472) explains that "organizational structure is the formal system of task and job reporting relationships. The organizational structure is a formal system, task relations, and job reporting that determines how employees use resources to achieve organizational goals. Kinicki and williams, (2011: 237) argue: Organizational structure is the formal system of tasks and coordination of the organization's goals.

Robbins and Coulter, (2009: 201) defines the organizational structure:

Organizational structure is the formal arrangement of job within an organization. When manager create or change the structure, they're engaged in organizational design, a process that involves decisions about six key elements: work specialization, departementalization, chain of command, span of control, centralization and decentralization and formalization.

Philosophically, the organizational structure is nothing but a formal building framework of the division of labor, power and coordination of work that allows the flow of information and communication effective and efficient to the organization in achieving goals. In this regard, McShane and Glinow (2008: 430) argue that the organizational structure is "the division of labor and the patterns of coordination, communication, work flow and formal power of direct of organizational activities". Division of labor such as patterns of coordination, communication, work flow, and formal power directly related to organizational activities.

So it can be synthesized that the organizational structure is a visualization framework that describes the relationship of organized cooperation on a regular basis with the common goal, which in the framework shows the relationship of authority, responsibility, and cooperation of each part to achieve the goal with indicators: job specification, chain of command, formalization, centralization, and coordination.

\section{Leadership Style}


Daft, (2005: 81) "leadership is influence relationship between leaders and followers who intend real changes and outcomes that reflect their shared purposes". This concept affirms leadership is a relationship affecting leaders with followers who expect real change and the outcome is a common goal.

According to Ivancevich, Kanopaske and Matteson, (2008: 170) the style of leadership is "using influence in an organizational setting or situation, producting effects that are meaningful and have a direct impact on accomplishing challenging goals". In this concept the style of leadership uses influence in the circumstances and situation of the organization, and has a direct influence in meeting the challenges of purpose.

Furthermore Greenberg, (2010: 195-196) states that leadership style is "the process by which an individual influences other ways of helping attain group or organizational goals". Contains the sense of a process in which individuals influence others in ways that help achieve group and organizational goals.

According to Newstorm, (2002: 30) "leadership style is the manner and approach of providing direction, implementing people". This concept affirms the style of leadership is the way and approach to give direction to others.

Usman, (2011: 295-299) provides twenty leadership traits that his subordinates are expected to follow: (1) honesty; (2) breadth of view; (3) the ability to inspire; (4) competence; (5) justice; (6) willing to provide support; (7) wide thinking; (8) smart; (9) straightforward; (10) reliable; (11) brave; (12) willing to cooperate; (13) imagination; (14) care; (15) is determined; (16) adults; (17) ambitious; (18) faithful; (19) can control themselves; (20) independent. Of the twenty characteristics of leadership, the top traits are (1) honesty, (2) foresight, (3) inspiration, (4) competence.

Understanding the style of leadership above can be synthesized leadership style is a model used by the leadership of the organization in giving influence to subordinates, in order to direct and drive all activities in achieving organizational goals with indicators: instruction, consultation, participation, and delegation.

\section{Trust}

McKee, (2012: 50) suggests that "trust is the expectation by employees that a leader will act in an ethically justifiable manner, will have their best interests at heart, and will strive to achieve the organization's goals". In this case trust is the expectation of employees that a leader will act ethically justifiable, will have the best interests ethically justifiable, will have their best interests in the organization, and will strive to achieve organizational goals.

Allen, Plunkett, and Attner, (2013: 225) that "when trust is present, employees will feel comfortable as the organization move through change, even though change is threatening". When trust is present, employees will feel comfortable as an organizational step through change, even though the change is threatening.

The beliefs of Dennis and Michelle (2008: 34) have components in formulating beliefs that are four beliefs: 1) capacity for trust: willingness to trust, 2) contractual trust: belief in character , 3) communications trust: trust in openness and 4) competence trust: trust in ability. Thus trust is a reciprocal relationship of mutual belief in agreed performance, honest communication, expected competence, and the ability to relate openly.

Goetsch and Davis, (2013: 55) say that "trust is an essential ingredient in total quality. Total quality that depends on trust: communication, interpersonal relations, conflict management, problem solving, team work, employee involvement and empowerment, and customer focus ". Trust is an essential element in total quality. The amount of quality that depends on trust: communication, interpersonal relationships, conflict management, problem solving, teamwork, employee engagement and empowerment, and customer focus. Based on some understanding of the beliefs described above, it can be synthesized that what is meant by trust is one's belief in others that will give change in the future, 
with indicators: integrity, competence, consistency, loyalty, and openness.

The results of this study are expected to provide additional studies for all parties in the field of management, especially in management education in formulating and determining policy steps of an institution in the future, academically, this research can enrich the concept or theory that support the development of science management education, related to the influence of organizational structure, leadership style, and trust, on performance. Practically, this research can provide useful input for an organization to improve its performance.

\section{METHOD}

This research was conducted in private SMP Palembang city. The purpose of this study is to test: (1) direct influence of organizational structure on performance; (2) direct influence of leadership style on performance. The method used is survey method. The study population was 1773 private junior high school teachers of Palembang. The sample of this study were 326 teachers. Determination of samples with Slovin formula. Data analysis technique using path analysis technique. After the data obtained, the data will be analyzed using path analysis technique with SPSS 22.0 for windows.

\section{RESULTS}

The results of research include three parts, namely: (1) description of data describes the characteristics of respondents and data from each research variable; (2) testing of analysis requirements whose results serve as a basis for establishing data analysis techniques; (3) hypothesis testing discusses the process of processing and the results of data analysis to explain empirically the relationship between research variables.

After data obtained from private junior high school teachers in Palembang city were processed and analyzed through various required tests, the next step in testing the causality model is to conduct path analysis. Based on theoretically formed causal model we will get the path analysis diagram and calculate the coefficient value of each path.

\section{Test of Estimated Error Normality}

\section{a. Test Normality Data Score Teacher Performance Error (Y) on Organizational Structure} (X1)

Based on the calculation of normality of regression estimate calculation is: $\hat{Y}=a+b X 1$ obtained $\alpha$ constant value and the value of slope $b$ obtained equation $\hat{Y}=13.961+0.864 \mathrm{X} 1$, then obtained Lhitung $=0.000$, while Ltabel with respondents 326 people $(\mathrm{n}=326)$ at $\alpha=0.05$, of 0.04908. Thus it can be argued that the distribution of assessment tools of teacher performance regression equation (Y) on the organizational structure (X1) in private junior high school in Palembang normal distribution.

\section{b. Test Normality Data Score Teacher Performance Error (Y) over Leadership Style (X2)}

Based on the calculation of normality of regression estimation error is: $\hat{Y}=a+b X 2$ obtained $\alpha$ constant value and the value of slope $b$ obtained equation $\hat{Y}=29.734+0.717 \mathrm{X} 2$, then obtained Lhitung $=0.000$, while Ltabel with respondents 326 people $(n=326)$ at $\alpha=0.05$, of 0.04908 . Thus it can be argued that the apparatus distribution of teacher teacher regression (Y) regression equations for leadership style (X2) in private SMP in Palembang city is normally distributed.

\section{c. Test Normality Data Score Teacher Performance (Y) Above Trust (X3)}

Based on the calculation of normality of regression estimate calculation is: $\hat{Y}=a+b X 2$ obtained $\alpha$ constant value and slope $b$ value obtained equation $\hat{Y}=12.433+0.878 \mathrm{X} 3$, then obtained Lhitung $=0.000$, while Ltabel with respondents 326 people $(n=326)$ at $\alpha=0.05$, of 0.04908 . Thus, it 
can be argued that the distribution of assessment tools of teacher performance regression equation (Y) on trust (X3) in private junior high school in Palembang normal distribution.

\section{d. Test Normality Data Score Error Trust (X3) on Organizational Structure (X1)}

Based on the calculation result of normality of regression estimation error is: $\dot{X} 3=a+b X 1$ obtained by constant value $\alpha$ and slope $\mathrm{b}$ value obtained equation $\dot{\mathrm{X}} 3=0.103+0.997 \mathrm{X} 1$, then obtained Lhitung $=0.000$, while Ltabel with respondent 326 people $(n=326)$ at $\alpha=0.05$, of 0.04908 . Thus, it can be argued that the distribution of appraisal of trust regression equation (X3) over organizational structure (X1) in private junior high school in Palembang is normally distributed.

\section{e. Test Normality Data Score Trust (X3) over Leadership Style (X2)}

Based on the calculation of normality of regression estimation error is: $\dot{X} 3=a+b X 2$ obtained $\alpha$ constant value and the value of slope $\mathrm{b}$ obtained equation $\dot{\mathrm{X}} 3=14.425+0.868 \mathrm{X} 2$, then obtained Lhitung $=0.000$, while Ltabel with respondents 326 people $(\mathrm{n}=326)$ on $\alpha=0.05$, of 0.04908. Thus, it can be argued that the appraisal distribution of trust regression equation (X3) over leadership style (X2) in private SMP in Palembang city is normally distributed.

Based on the results of the overall calculation error normality test in this study can be seen in the following table summary 4.6.

Table 4.6 Summary of Normality Error Test

\begin{tabular}{|c|c|c|c|c|c|c|}
\hline \multirow{2}{*}{ No. } & \multirow{2}{*}{ Estimated error } & \multirow{2}{*}{$\mathbf{N}$} & \multirow{2}{*}{$\mathbf{L}_{\text {Count }}$} & \multicolumn{2}{|c|}{$\mathbf{L}_{\text {table }}$} & \multirow{2}{*}{ Decision } \\
\hline & & & & $\alpha=\mathbf{0 , 0 5}$ & $\alpha=0,01$ & \\
\hline 1. & Y On $X_{1}$ & 326 & 0,000 & 0,04908 & 0,0571 & Normal \\
\hline 2. & Y On $\mathrm{X}_{2}$ & 326 & 0,000 & 0,04908 & 0,0571 & Normal \\
\hline 3. & Y On $X_{3}$ & 326 & 0,000 & 0,04908 & 0,0571 & Normal \\
\hline 4. & $\mathrm{X}_{3}$ On $\mathrm{X}_{1}$ & 326 & 0,000 & 0,04908 & 0,0571 & Normal \\
\hline 5. & $\mathrm{X}_{3}$ On $\mathrm{X}_{2}$ & 326 & 0,000 & 0,04908 & 0,0571 & Normal \\
\hline
\end{tabular}

Source: Appendix 5 (pages 339-363)

In accordance with the description above, the estimated error conditions have been met.

\section{Significant Test and Linearity of Regression and Correlation Coefficiency}

The last test required before the analysis is a test of significance and linearity of the regression model. The linearity test intends to test whether the regression line of the independent variable over the dependent variable has a linear relationship or vice versa. If both data have direct relationship.

To test the linearity of data used F-test, with the following test criteria:

H0: Model is linearly patterned, if Fcount $\leq$ Ftable

H1: The patterned model is not linear, if Fcount $>$ Ftable

Based on the data calculation procedure, hypothesis testing can be performed for linearity test, as follows:

Significance Test Results Regression Model

\begin{tabular}{|c|c|c|c|c|c|}
\hline \multirow{2}{*}{ No. } & \multirow{2}{*}{$\begin{array}{l}\text { Relationship Models } \\
\text { between Variables }\end{array}$} & \multirow{2}{*}{$\mathbf{F}_{\text {Count }}$} & \multicolumn{2}{|c|}{$\mathbf{F}_{\text {table }}$} & \multirow{2}{*}{ Decision } \\
\hline & & & $\mathbf{0 , 0 5}$ & 0,01 & \\
\hline 1. & Y On $X_{1}$ & 764.368 & 2.41 & 3.40 & Significant \\
\hline 2. & $\mathrm{Y} \mathrm{On} \mathrm{X}_{2}$ & 207.368 & 2.41 & 3.40 & Significant \\
\hline 3. & Y On $X_{2}$ & 833.928 & 2.41 & 3.40 & Significant \\
\hline 4. & $\mathrm{X}_{3}$ On $\mathrm{X}_{1}$ & 2.94334 & 2.41 & 3.40 & Significant \\
\hline 5. & $\mathrm{X}_{3}$ On $\mathrm{X}_{2}$ & 512.888 & 2.41 & 3.40 & Significant \\
\hline
\end{tabular}

Source: Appendix 5 (pages 339-363)

While the regression linearity test results (Linearity-F test) also shows that regression regression model Y over X1, Y over X2, Y over X3, X3 over X1, X3 over X2, X2 over X1, X2 over X3, X1 over 
$\mathrm{X} 2$, $\mathrm{X} 1$ over $\mathrm{X} 3$, shows everything is linearly patterned. Overall summary test linearity test regression model can be seen in the following table 4.13:

Table 4.13. Summary of Linearity Test Results Regression Model

\begin{tabular}{|l|l|c|c|c|c|}
\hline \multirow{2}{*}{ No. } & Relationship Models & \multirow{2}{*}{ F $_{\text {Count }}$} & \multicolumn{2}{|c|}{ F $_{\text {table }}$} & \multirow{2}{*}{ Decision } \\
\cline { 4 - 5 } & between Variables & (Tuna fit) & $\mathbf{0 , 0 5}$ & $\mathbf{0 , 0 1}$ & \\
\hline 1. & Y On $\mathrm{X}_{1}$ & 1.563 & 2.41 & 3.40 & Linear \\
\hline 2. & ${\text { Y On } \mathrm{X}_{2}}_{3 .}$ & 3.122 & 2.41 & 3.40 & Linear \\
\hline Y On $\mathrm{X}_{2}$ & 1.719 & 2.41 & 3.40 & Linear \\
\hline 4. & $\mathrm{X}_{3}$ On $\mathrm{X}_{1}$ & 2.341 & 2.41 & 3.40 & Linear \\
\hline 5. & $\mathrm{X}_{3}$ On $\mathrm{X}_{2}$ & 2.060 & 2.41 & 3.40 & Linear \\
\hline
\end{tabular}

Source: Appendix 5 Anova table (pages 339-363)

\section{Calculation of path coefficients}

After data obtained from private junior high school teachers in Palembang city were processed and analyzed through various required tests, the next step in testing the causality model is to conduct path analysis. Based on theoretically formed causal model we will get the path analysis diagram and calculate the coefficient value of each path.

The Empirical Causal Relationship Model between X1, X2, X3 to Y

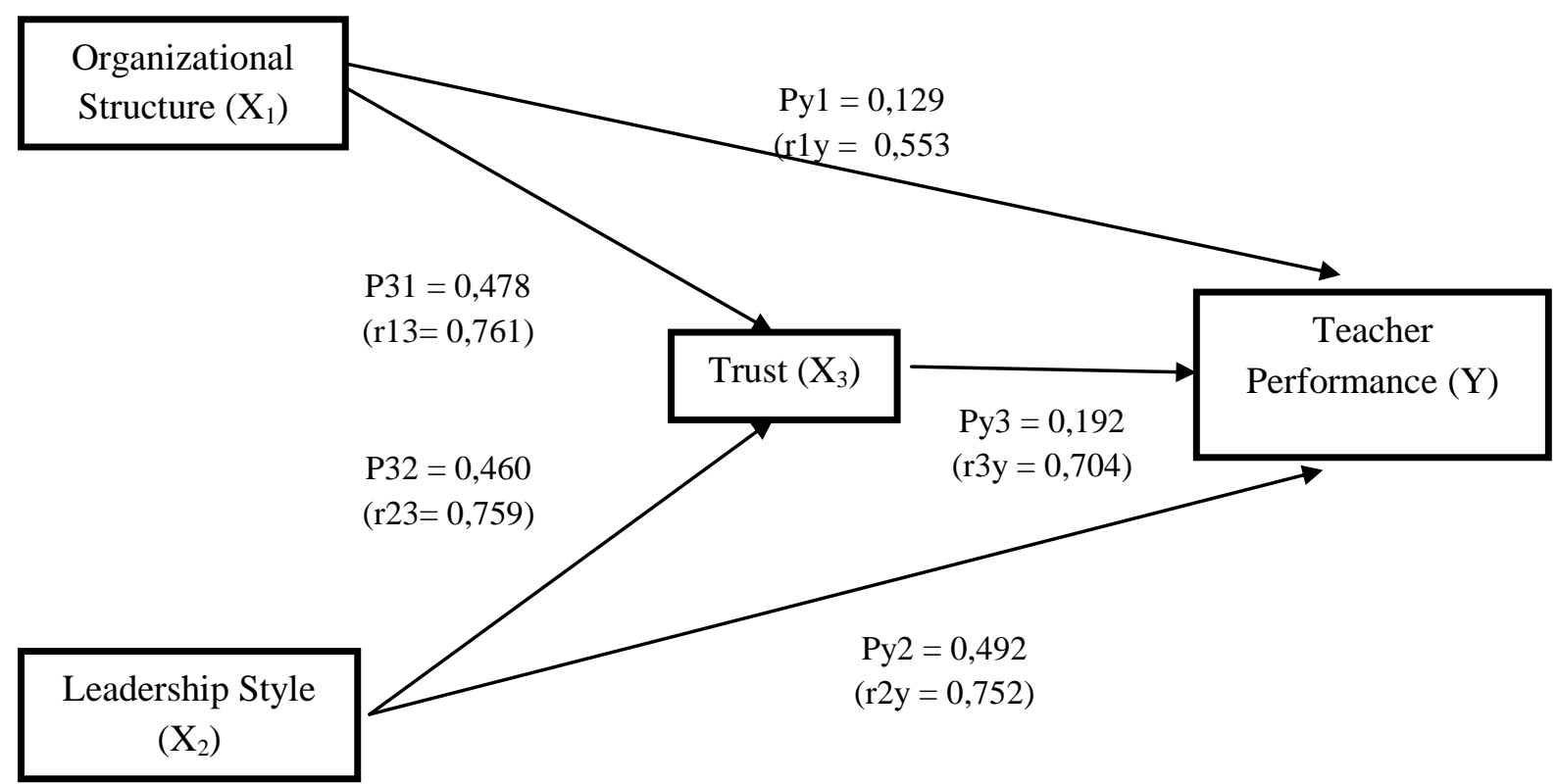

Figure 4.8 Keofisiensi Lines Organizational Structure, Leadership Style, Belief in Teacher Performance

Recapitulation of Hypothesis Testing Results

\begin{tabular}{|l|l|l|l|l|}
\hline Variable & Path Coefficiency & $\mathbf{T}_{\text {Count }}$ & $\mathbf{t}_{\text {table }}$ & Decision \\
\hline \hline $\mathrm{X}_{1}$ To Y & $\left(\rho_{\mathrm{y} 1}\right)=0.129$ & 2.331 & 1.87 & $\begin{array}{l}\text { Ho is rejected and H1 accepted. There } \\
\text { is a positivedirect effect of } \\
\text { organizational structure (X1) on } \\
\text { teacher performance }(\mathrm{Y})\end{array}$ \\
\hline $\mathrm{X}_{2}$ To Y & $\left(\rho_{\mathrm{y} 2}\right)=0.492$ & 8.531 & 1.87 & $\begin{array}{l}\text { Ho is rejected and H1 accepted. There } \\
\text { is a positive direct influence of } \\
\text { leadership style (X2) on teacher } \\
\text { performance }(\mathrm{Y})\end{array}$ \\
\hline $\mathrm{X}_{3}$ To Y & $\left(\rho_{\mathrm{y} 3}\right)=0.192$ & 2.799 & 1.87 & $\begin{array}{l}\text { Ho is rejected and H1 accepted. There } \\
\text { is a positive direct effect of trust }(\mathrm{X} 3)\end{array}$ \\
\hline
\end{tabular}




\begin{tabular}{|l|l|l|l|l|}
\hline & & & & on teacher performance (Y) \\
\hline $\mathrm{X}_{1}$ To $\mathrm{X}_{3}$ & $\left(\rho_{31}\right)=0.478$ & 12.691 & 1.87 & $\begin{array}{l}\text { Ho is rejected and H1 accepted. There } \\
\text { is a positive direct effect of } \\
\text { organizational structure (X1) on trust } \\
(\mathrm{X} 3)\end{array}$ \\
\hline $\mathrm{X}_{2}$ To $\mathrm{X}_{3}$ & $\left(\rho_{32}\right)=0.460$ & 12.197 & 1.87 & $\begin{array}{l}\text { Ho is rejected and H1 accepted. There } \\
\text { is a positive direct influence of } \\
\text { leadership style (X2) on trust (X3) }\end{array}$ \\
\hline
\end{tabular}

The result of calculation through SPSS 22.0 obtained by path coefficient on substructure-1 can be presented in the following table:

Table 1 Coefficient Values of Paths on Substructure-1

\begin{tabular}{|l|l|l|l|l|l|}
\hline \multirow{2}{*}{ Model } & \multicolumn{2}{|l|}{$\begin{array}{l}\text { Unstandardized } \\
\text { Coefficients }\end{array}$} & $\begin{array}{l}\text { Standardized } \\
\text { Coefficients }\end{array}$ & t & Sig \\
\cline { 2 - 7 } & $\boldsymbol{\beta}$ & Std Error & Beta & & 0.000 \\
\hline Constant & 21.056 & 4.462 & & 4.719 & 0.020 \\
\hline Organizational structure (X1) & 0.139 & 0.059 & 0.129 & 2.331 & 0.029 \\
\hline Leadership Style (X2) & 0.481 & 0.056 & 0.492 & 8.531 & 0.000 \\
\hline
\end{tabular}

From table 1 above we can show the path model of substructure-1 then the empirical causal relationship between variables $\mathrm{X} 1, \mathrm{X} 2, \mathrm{X} 3$ to $\mathrm{Y}$ in substructure-1 as follows: $\hat{\mathrm{Y}}=0.129 \mathrm{X} 1+0.492 \mathrm{X} 2$

After structural model analysis has been done, the results obtained are used to test the hypothesis to meet the direct and indirect effects between variables. The proposed hypothesis will be concluded through the calculation of the path coefficient and significant values for each path under study. The results of the first hypothesis test show that the organizational structure (X1) has a direct effect on teacher performance $(Y)$ From the calculation results obtained by the coefficient value $(\rho y 1)=0.129$ with tct $=4.719$, while the ttable at the real level then $\alpha=0.05$ obtained the number 1.87 because tcount> ttable, then in accordance with the criterion test Ho start and accept H1. Thus there is a direct influence variable organizational structure $(\mathrm{X} 1)$ on teacher performance $(\mathrm{Y})$. This means that the better the organizational structure will lead to increased performance of private junior teachers in the city of Palembang.

Result of second hypothesis: leadership style (X2) have direct effect to teacher performance (Y). From the calculation results obtained by the coefficient value of the path $(\rho y 2)=0.492$ with tcount $=$ 2.351, while the ttable at the real level then $\alpha=0.05$ obtained the number 1.87 for tcount $>$ ttable, then in accordance with the Ho Ho accept test criteria and accept H1. Thus there is a direct influence of leadership style (X2) on teacher performance (Y). This means that the better leadership style will lead to increased performance of private junior teachers in the city of Palembang.

\section{DISCUSSION}

\section{Direct positive influence of organizational structure (X1) on teacher performance (Y)}

The results of this study indicate that the organizational structure has a direct positive effect on teacher performance. The findings of this study indicate that organizational structure positively determines teacher performance. The results of this study have given the direction that the organizational structure is closely related to the improvement of teacher performance. Teacher performance is determined by the organizational structure applied by the head / principal.

This result is reinforced by Rifa'I's (2017: 28) research "Relationship between Leadership Style, Organizational Structure, Achievement Motivation, and Commitment to Organization, with Lecturer Performance at Universities in Pesantrens in East Java". The results of this study concluded as follows 
organizational structure is needed in directing the performance of the members of the organization, because the performance shown by the members of the organization will have an impact on the achievement of overall organizational goals.

Thus the findings of facts and data in the analysis of this study further support the existence of a very strong direct influence between organizational structure and teacher performance.

\section{Direct positive influence of leadership style (X2) on teacher performance (Y)}

The results of this study indicate that leadership style has a direct positive effect on teacher performance. The findings of this study indicate that leadership style positively determines teacher performance. The results of this study have given the direction that leadership style is closely related to teacher performance improvement. Teacher performance is determined by the leadership style applied by the leader / principal.

So in accordance with previous research conducted by Jing and C. Avery (Vol.7, Number 5, May 2008. pp. 67-78), entitled Missing Link in Understanding the Relationship Between Leadership and Organizational Performance, "found that leadership creates relationships which is important between organizational effectiveness and the performance of people at an organizational level.

Thus the findings of facts and data in the analysis of this study further support the existence of a very strong direct influence between organizational structure and teacher performance

\section{Direct positive influence of trust (X3) on teacher performance (Y)}

The results of this study indicate that trust has a positive direct effect on teacher performance. The findings of this study show that trust positively determines teacher performance. The results of this study have given the direction that trust is closely related to teacher performance improvement. Teacher performance is determined by the trust applied by the leader / principal.

This is reinforced by previous research conducted by Roxanne Zolin, Pamela J. Hinds, (2004: 214-238) entitled Trust in Context: The Development of Interpersonal Trust in Geographically Distributed Work. In Trust and Distrust in Organization. "It was found that trust is influenced by many factors such as the number and quality of communication, perceptions of followers, risk, leadership and formalization. Meanwhile, trust affects the openness of the organization, the work, and the work processThus the findings of facts and data in the analysis of this study further support the existence of a very strong direct influence between organizational structure and teacher performance.

\section{Direct positive influence of organizational structure (X1) on trust (X3)}

The results of this study indicate that the organizational structure has a direct positive effect on trust. The findings of this study indicate that organizational structure positively determines trust. The results of this study have given the direction that the organizational structure is closely related to the increase of trust. Trust is determined by the organizational structure applied by the head / principal.

This is reinforced by the opinion of Colquitt, Lepine and Wesson, (2015: 505) explains that there are five dimensions within the organizational structure that describe the relationships of tasks, authorities, and responsibilities of decision-makers in the organization:

a. Work specialization: The degree to which tasks ini an organization are devided into separate jobs. (specialization of work: the degree to which tasks within the organization are divided into separate occupations.

b. Chain of command: answers the question of "who reports to whom?" and signifies formal authority relationships. (chain of command: the answer to who questions report to whom? And explains the formal authority. 
c. Span of control: represents how many employees each manager in the organization has responsibility for. (level of supervision: represents multiple employees for each manager in the organization for whom it is responsible).

d. Centralization: refers to where decisions are formally made ini organizations (centralization: refers to where decisions are made formally within the organization).

e. Formalization: the degree to which rules and prosedures are used to standardize behaviors and decisions in an organization. (formalization: the degree to which rules and procedures are used to standardize behaviors and decisions within an organization).

Structure is a process that starts from organizational goals, then strategy, that is steps taken for the achievement of goals. Daft (2012: 72) describes the relationship between organizational structure and decision making that is:

a. The set of formal tasks assigned to individuals and departement.

b. Formal reporting relationships, including lines of authority, decision, responsibility, number of hierarchical levels, and span of manager's control.

c. The design of system to ensure effective coordination employees across departement.

The organizational structure is (1) divides the formal tasks of individuals and departments, (2) formal reporting relationships including lines of authority, responsibility, decision making, number of hierarchical levels, and control management; and (3) system design to ensure effective coordination of employees who are in the department.

Thus it can be said that to design the organizational structure, the leadership has a strategic role in doing a decision-making process to divide the work, duties, and responsibilities, the pattern of coordination relationships, communication, workflow, and allocate resources in the organization that will lead to confidence for members of the organization.

Thus the findings of facts and data in the analysis of this study further support the existence of a very strong direct influence between organizational structure and trust.

\section{Direct positive influence of leadership style (X2) on trust (X3)}

The results of this study indicate that leadership style has a positive direct effect on trust. The findings of this study indicate that leadership style positively determines trust. The results of this study have given the direction that leadership style is closely related to increased trust. Trust is determined by the leadership style applied by the leader / principal.

This is in line with the theory of integrative model of the behavior of the organization Colquitt, Jeffrey A. LePine and J. Wesson, (2012: 8) which states that performance in an organization is one individual outcomes, influenced by individual mechanisms, one of which is trust ). Trust is influenced by organizational culture and leadership. With a conducive atmosphere created by the leader will certainly create a positive confidence of the personnel to the leadership in the organization. Self-belief is defined as a desire to rely on an authority based on positive expectations of action and attention of authority. Thus, the leader must choose the right style in his / her leadership with the purpose of the style can give positive impact to the employees, so that the trust of employees in the organization become big and positive to the leader.

\section{CONCLUSION}

The conclusion of the research result entitled "The Influence of Organizational Structure, Leadership Style, and Trust on the Performance of Private Junior Teachers in Palembang City, can be summarized as follows, (1) organizational structure has a positive direct effect on teacher performance. This means that the school organization structure in accordance with the needs in the field, will lead to increased performance of private junior teachers in the city of Palembang. (2) leadership style has a 
positive direct effect on teacher performance. This means that the principal leadership style applied in schools that suits the needs in the field, will lead to increased performance of private junior high school teachers in the city of Palembang.

Based on the conclusions of this study, the implications of research regarding the organizational structure, leadership style and beliefs on the performance of private junior high school teachers in Palembang City, can be explained as follows: Organizational structure has a direct positive effect on teacher performance. The implications for improving teacher performance, schools require a good organizational structure with indicators, namely job specialization, chain of command, formalization, communication and coordination, as well as the skills and role of each teacher in the school, so that every teacher in the school has a role and responsibility answer to coordinate with other teachers and perform their duties so as to improve their performance. The style of leadership has a direct positive effect on teacher performance. The implication is by applying a good leadership style, principals can motivate teachers 'performance in teaching and learning activities in schools, principals can set an example and work with teachers to improve the quality of teachers' learning and performance in schools.

\section{REFERENCES}

Angelo Kinicki and Brians Williams. (2011) Management. New York: McGraw-Hill-Irwin.

Annie McKee. (2012) Management: A Fokus On Leaders. New Jersey: Pearson Education.

Anwar Prabu Mangkunegara. (2009). Manajemen Sumber Daya Manusia Perusahaan. Bandung: Remaja Rosdakarya.

Brahmasari, Ida Ayu, Siregar, Peniel. (2009). "Pengaruh Budaya Organisasi, Kepemimpinan Situasional dan Pola Komunikasi terhadap Disiplin Kerja, dan Kinerja Karyawan pada PT. Central Protoeinaprima Tbk", Jurnal Aplikasi Manajemen, JAM, Jurusan Manajemen Universitas Brawijaya.

Colquitt, Jason A., Lepine Jeffery A. Wesson Michael J. (2015). Organizational Behaviour. Improving Performance and Commitment in the Workplace, $4_{\text {th }}$ Ed. NewYork: McGraw-Hill Education.

Daft, Richard L. (2012). New Era Management, Tenth Edition. Canada: South Western, Cengage Learning.

David L. Goetsch dan Stanley Davis. (2013). Quality Management for Organizational Excellence: Introduction to Total Quality, $7^{\text {th }}$ Ed. New Jersey: Pearson Education.

Dennis S. Reina \& Michelle L.Reina. (2008). Trust \& Betrayal in the Workplace, Membangun Hubungan yang efektif dalam dunia kerja, terjemahan Andry Kristiawan S. Jakarta: Penerbit Matahati.

Fenwick Feng Jing and Gayle C. Avery. (2008). "Missing Link in Understanding The Relationship Between Leadership and Organizational Performance, "Econbiz Online; International Bussiness and economic Research Journal.

Greennberg, Jerald. (2010). Managing in Organization, $5^{\text {th }}$ Edition. New Jersey: Pearson Education, Inc.

Husaini Usman. (2011). Manajemen. Teori, Praktik, dan Riset Pendidikan. Jakarta: Bumi Aksara.

James L. Gibson, Ivancevich, John M, Donelly, James H, JR and Robert, Konopaske. (2012). Organizations: Behaviour, Structure, Processes. New York: McGraw-Hill-Irwin

Jason A. Colquitt,Jeffrey A. Lepipn and Michael J. Wesson. (2009). Organizational Behavior, Improving Performance Commitment in The Workplace. New York: McGraw-Hill Irwin.

Jeniffer M. George and Gareth R. Jones. (2012). Understanding and Managing Organizational Behavior. New Jersey: Pearson Education.

Jerald Greenberg. (2010). Managing behavior in Organization. New Jersey: Pearson Education.

Jhon M.Ivancevich, Robert Konopaske, Michael T. Matteson. (2008). Organizations Behavior and Management,8nd Edition. Singapore: McGraw-Hill/Irwin.

John W. Newstorm, Keith Davis. (2002). Organizational Behavior: Human Behavior at Work. New York: McGraw-Hill-Irwin. 
Judith A. Hale. (2004). Performance Based Management: What Every Manager Should Do To Get Results. San Francisco: John Wiley \& Sons.

Mulyasa. (2004). Manajemen Berbasis Konsep. Bandung: Remaja Rosda Karya.

Newstorm, John W. (2007). Organizational Behaviour: Human Behaviour at Work. New York: International Edition: McGraw-Hill/Irwin.

Richard L. Daft. (2005). The Leadership Experience, Third Edition. South Western: Thompson Corporation.

Rivai, Veithzal and Sylviana Murni. (2009). Education Management, Analisis Teori dan Praktik. Jakarta: Rajawali Pers.

Roxane Jolin, Pamela J. Hinds. (2004). "Trust in context: The Development Interpersonal in Geographically Distributed Work, In Trust and Distrust in Organization," Eds Roderick M, Kramer, and Karen cook for Russell Sage Foundation New York (http://touch.www.linkedin.com/ diakses tanggal 21 Desember 2016).

Sedarmayanti. (2009). Reformasi Publik, Reformasi Birokrasi, dan Kepemimpinan Masa Depan, Mewujudkan Pelayanan Prima dan Pemerintahan yang Baik. Bandung: Refika Aditama.

Stephen P. Robbins and Mary Coulter. (2009). Management. New Jersey: Prentice-Hall.

Steve M. Jex and Thomas W. Britt. (2008). Organizational Psychology: A Scientist-Practionioner Approach. New Jersey: John Wileys \& Sons.

Steven L McShane and Mary Ann Von Glinow. (2008). Organizational Behaviour, Fourth Edition. New York: McGraw-Hill.

Stoner, James and A.f. Freeman. (1998). Management. Jakarta: Prehalindo.

Sugiyono. (2009). Metode Penelitian Administrasi, ed.Rev, cetakan 17. Bandung: Alfabeta.

Thoha, Miftah. (1983). Perilaku Organisasi, Konsep Dasar dan Aplikasinya. Jakarta: PT Raja Grafindo Persada.

Tope Adeyemi Bello. (2001). “The Impact of leadership Style on Organizational Growth". Work Study

Usman, Husaini. (2011). Manajemen. Teori, Praktik, dan Riset Pendidikan. Jakarta: Bumi Aksara.

Usman, Nurdin. (2002). Konteks Implementasi Berbasis Kurikulum. Jakarta: PT. Raja Grafindo Persada. 